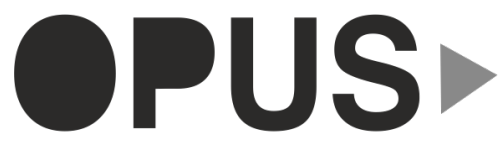

Uluslararası Toplum Araştırmaları Dergisi International Journal of Society Researches
E-ISSN : 2528-9535

YIl Year: 9

Cilt Volume: 14

Sayı Issue :20

Aralık December 2019

Makalenin Geliş Tarihi Received Date: 31/08/2019

Makalenin Kabul Tarihi Accepted Date: 24/12/2019

\title{
Türk Modernleşmesinde Halkevlerinin Yeri
}

\author{
DOI: 10.26466/opus.656129
}

$*$

\section{Songül Gökçe*}

${ }^{*}$ Y. L Öğrencisi. Bülent Ecevit Üniversitesi, Sosyal Bil. Ens. Tarih ABD, Zonguldak

E-Posta: songul-gokce-23@hotmail.com

ORCID: 0000-0002-7779-7172

\section{Öz}

Türkiye Cumhuriyeti Devleti'nin kuruluşunda ve Türk modernleşmesinde önemli bir yere sahip olan halkevlerinin kurulma, gelişme, yayginlaşma sürecini incelemekteyiz. Cumhuriyetle birlikte yeni devletin toplumunu eğitmek, devletin halka önem verdiğini vurgulamak, yapilan inkilaplarm benimsenmesini sağlamak ve halkı üretime, yenileşmeye dâhil etmek için halkevlerinin kurulması öngörülmüştür. Halkın eğitim düzeyinin düşük olması ve yapılan yeniliklerin hızl bir şekilde hayata geçirmek istenmesi birbiriyle çatışmaktaydı. Bu zorluğun açı̆̆a çıkması aslında halkın eğitime ne derecede muhtaç bir şekilde olduğunu da göstermekteydi. Bunun yanında okuma yazma eğitimleri ve kültürel faaliyetlerin içerisinde Cumhuriyet değerlerinin halka benimsetilmesi ve anlatılması gerekmekteydi. Bu durumu etkili ve önemli bir şekilde çözüme gelmediği sürece inkllâplar yine halkta karşıllı bulamayacak ve geçerliliğini yitirecektir. Illke ve değerlerin kalıcı olup korunması ancak halk desteğiyle mümkün olabilirdi. Halk arasında derin yankılar uyandıran ve büyük önem taşıyan halkevlerinin topluma etkisini bu şekilde vurgularken de faaliyetlerini nasıl ne yöntemlerle sürdüklerini, dolayısıyla da halkın eğitilmesi, aydınlatılması, halkın yönetime katılması sürecindeki gelişmeleri hakkında bilgilendirme incelemesinde bulunacağız.

Anahtar Kelimeler: Modernleşme, Halkevleri, Toplum, İnkılap 


\title{
Turkish the Modernization Community Centers of Place
}

\begin{abstract}
The establishment of the Republic of Turkey and the establishment of community centers which have an important place in Turkish modernization, the establishment, we have been observing in the dissemination. Together with the republic, it is emphasized that the state of the new state should be educated, the state attaches importance to the people, and it expects the reforms to be adopted and wants to have people's houses in order to direct the people towards production and innovation. The low level of education of the public and the desire to rapidly implement the innovations were in conflict with each other. The fact that this difficulty was revealed also showed the need of the public for education. In addition, the values of the Republic should be adopted and explained to the public in literacy trainings and cultural activities. Unless this situation is solved effectively and importantly, the revolutions will not be able to find any response in public again and it will lose its validity. Permanent preservation of principles and values could only be possible with public support. While emphasizing the impact of the community houses, which have deep repercussions among the people and which are of great importance, we will examine how they continue their activities in this way, and thus inform the public about the developments in the process of education, enlightenment and participation of the people in the management.
\end{abstract}

Keywords: Modernization, Folk House, Society, Revolutions. 


\section{Giriş}

Türkiye Cumhuriyeti Devleti'nin kuruluşunu hazırlayan birçok etken bulunmaktadır. Bu etkenlerden herhangi biri için kesin bir neden olarak bahsetmek mümkün olmadığı gibi ortaya çıkan nedenlerin hepsinin az ya da çok etkili olduğu bilinmektedir. Mustafa Kemal Türkiye Cumhuriyeti'nin varlığını sürdürmesinin eğitimle ilintili olduğunu bağdaştırmıştır. Yeni kurulan Türkiye Cumhuriyeti'nde sadece gençlerin değil yetişkinlerinde eğitilmesi gerektiğini savunmuştur. Bu doğrultuda ülkede yapılan yeniliklerin halka anlatılması için Halkevlerinin kurulması yönünde bir ihtiyacın doğduğunu belirtmiştir.

\section{Halkevlerinin Ortaya Çıkışı ve Siyasi Yapısı}

Türk halkı son yüzyılın başlarında içinde bulunduğu sosyal, siyasal ve ekonomik şartlar çerçevesinde yok olma tehlikesiyle karşı karşıya gelmiştir. Bu şartlar içerisinde öncelik milletin ve devletin bekasını sağlamak olmuştur. Bu mücadeleden sonra yeni kurulan devletin ayakta kalabilmesi ve varlığını sürdürebilmesi için Cumhuriyeti ve değerlerini benimsemiş, eğitimli, bilinçli ve sosyal anlamda refah içerisinde yaşayan bir halk anlayışına ihtiyaç vardı. Bu temel olguyu gerçekleştirmek için halkevlerinin kurulması ve yaygınlaştırılması esas hedef haline gelmiştir. Halkevleri Türk inkılaplarının görünür hale gelmesidir. Halkçılık temeline oturtulan halkevlerinin kuruluş amaçları çok çeşitlidir. Öncelikle yüzlerce yıldır yaşadığı toprakları ve medeniyetini tanıtarak milli bilinci uyandırmaktır. Bunun doğal bir sonucu olarak kendi tarihine, kültürüne inanan bilimsel bilgiyi ön planda tutan bir toplum oluşturmaktı. Bu sayede Türklerin barbar ve medeniyetsiz olduğu görüşü de ortadan kalkacaktı.

Türklerin tarihinin sadece Osmanlı ile sinırlı olmadığ 1 Orta Asya'dan beri edebiyat alanında eserler verdiği halkevlerinin faaliyetleri arasındadır. Milli değerlerin nesilden nesile aktarılmasında Cumhuriyet'in kurulduğu yıllarda kilit bir rol oynamıştır. (Ortaylı, 2018, s. 102-125)

Halkevlerinden önce halk eğitim kuruluşları olarak, Halk Eğitimi Şubesi, Halk Derslikleri (1927), Halk Okuma Odaları (1930) kurulmuş ve önemli faaliyetlerde bulunmuşlardır. 1932 yılında açılan Halkevleri ve 
1940 yıllarında açılmaya başlayan halk odaları ile birlikte birçok alanda hizmet vermiştir. Halkevlerinin genel olarak çalışma konuları dil ve edebiyat, temsil, güzel sanatlar, sosyal yardım kütüphane ve yayın, halk dershaneleri ve kurslar, köycülük, Spor, tarih ve müze şeklindedir. Bu çalışma alanlarının çeşitliliği, her vatandaşın kendi kabiliyetlerine göre bir meşguliyet alanı bulabilmesini sağlamaktır. (Kaya, 2008, s. 12)

Halkevleri kültürel anlamda faaliyetler yürüterek toplumda bilinçlendirmeyi amaç edinmesinin sosyal dayanışma kurumları olarak da hizmet vermiştir. Osmanlı döneminde de milli birlik oluşturmayı hedefleyen Türk Ocakları vardı. 19. yüzyılda Osmanlı'da ortaya çıkan Fikir Akımlarından biri Pantürkizm faaliyetleri sonucunda 1911 yılında Türk Ocakları kurulmuştu.

Türkçülük ile ilgili çalışmalar yapan Türk Ocakları Milli Mücadele'ye katkıda bulunmuşlardı. Kültürel anlamda çalışmaları olan Cumhuriyet döneminde Ankara'ya taşınan Türk Ocakları Atatürk İnkılaplarının destekçisi ve takipçisi olmuştur. Genel merkezde bilimsel, sosyal ve kültürel faaliyetler düzenlenmiştir. Kendi imkânlarıyla halk okulları ve dispanserlerin kurulmasını sağlamıştır.

Kuruluşundan Atatürk'ün ölümüne kadar olan sürede, Halkevlerinin toplumdaki etkinlikleri çok fazlaydı. 1938 yılında Türkiye nüfusunun yarıya yakını Halkevlerinin faaliyetlerine katılmışlardır. Atatürk'ün ölümünden sonraki dönemlerde Halkevlerine katılım bu sayıda olmamıştır. Bunun da sebebi C.H.F'nin yeni yönetiminin köylünün kalkınması için Köy Enstitülerine ve şehirlerdeki Halkevleriyle bağlantıyı sağlamak amacıyla köylerde (Tunaya,2008, s.10) Halkodalarının kuruluşuna öncelik tanımasıdır. Halkevlerinin giderek sayıları istenen düzeyde artmadığı gibi 1947 yılından itibaren Halkevi açılmamıştır. Halkevlerinin öneminin ve işlevinin azalmasında radyonun, sinemanın ve gazetelerin de olumsuz etkileri olmuştur. II. Dünya savaşının bitiminden sonra Türkiye'de radyo ve sinema sayısında büyük artış olmuştur. Gazeteler okuyucu çekmek için fiyatlarını sabit tutmuşlar ilaveler çıkarmışlardır. Ancak en önemli neden siyasidir. 1946 yılından itibaren çok partili sisteme geçilmesiyle devlet memurlarının ve özellikle öğretmenlerin Halkevlerinde görevlendirilmeleri zorlaşmıştır. Muhalefet daima bunu C.H.F aleyhine bir koz olarak kullanmıştır. C.H.F de kendisine siyasi bir yarar 
sağlayamadığını gördüğü Halkevlerini artık sadece eskiden olduğu gibi bir kültür kolu olarak devam ettirmekte yarar görmemiştir.

1950 yılında iktidar olan DP ile Halkevlerinin durumu değişmiştir. 1951 yılında 5830 sayılı kanun ile Türkiye'deki tüm halkevleri kapatılmış, taşınmazları hazineye intikal etmiştir

1960 ihtilalinden sonra kurulan Anayasa mahkemesi C.H.F'nin müracaatı üzerine 6195 sayılı yasayı iptal edilmiştir. Ancak C.H.F'nin Halkevlerine ait binaları da almak suretiyle Halkevlerini yeniden canlandırmak konusunda bir çabası olmamıştır. O dönemdeki C.H.P Genel Başkanı İsmet İnönü, Halkevlerinin 1960 yılında kurulan Türk Kültür Dernekleri ile birleşerek faaliyetlerine devam edeceklerini söylemiştir. Bundan da 1946'dan itibaren Halkevlerinden uzaklaşan C.H.F'nin 1960'lı yılların ortasında bile aynı tavrı koruduğu anlaşılmaktadır. 1930'lu ve 40'lı yıllarda büyük atılımlar yapan Halkevlerinin benzer işlevlerini bugün birbirleriyle ilgisi bulunmayan devlet kuruluşları, vakıflar, dernekler ve özel kuruluşlar üstlenmiştir.

\section{Türk Ocaklarının Kapanması}

Türkiye Cumhuriyeti'nin dokuzuncu yılında yani 1932 yılında kurulmuş olan Halkevlerinin geçmişi eskiye dayanmaktadır. Yaygın kanaatte göre, Halkevleri işleyiş ve faaliyetleri bakımından Türk Ocakları'nı model almıştır.

Türk Ocakları Osmanlı İmparatorluğu döneminde kurulmuştur. İmparatorluklar birçok milletten oluşan bir mozaiktir. 1789 Fransız İhtilali ile ortaya çıkan Milliyetçilik akımı, monarşileri etkilemiştir. Bu dönemde imparatorluklarda yaşayan birçok millet bağımsız olmak amacıyla isyan etmişlerdir.

Osmanlı İmparatorluğu da bu durumdan etkilenmiştir. Yusuf Akçura bu etkileşimin Osmanlı'yı nasıl etkilediğini şöyle anlatmıştır. "Her kavim, diğer kavimlere karşı daima kendi hususiyetini duymuş ve çoğunlukla kendi üstünlüğ̈̈nü iddia etmiştir. Bu duygu ve iddia, milliyetçilik fikrinin içgüdü ile meydana gelen ilk başlangıcıdır. Türk kavimlerinde bu duygu ve iddianın her zaman var olduğu hiç korkmadan tasdik edilebilir. Fakat söz konusu olan 'milliyet fikri', bu duygu ve iddianın çok gelişmiş bir safhasıdır." (Akçura, 2012, s.25-26.) 
19. yüzyılda Osmanlı'nın dağılmasını önlemek amacıyla Tanzimat sonrası aydınları birçok fikri akımı benimsemişlerdir: İslamcılık, Türkçülük, Osmanlıcılık gibi. Ancak ülkenin dağılma sürecinde uygulanan fikir akımlarının işe yaramaması, ekonomik ve siyasi çözülmeyle birlikte sömürgeleşmeye karşı bir güç birliği sağlanamamıştır. (Ortaylı, 2018, s.103130)

Temelleri Tanzimat dönemindeki aydınlarla oluşmuş olan Türk Ocakları II. Meşrutiyet Dönemi'nde 1912 yılında kurulmuştur. Aynı dönemde kurulan birçok dernek ve örgüt arasında varlığını en fazla sürdüren olmuştur. Osmanlı'nın kurtuluşunun Türkçülükle bağlantılı olduğunu dile getiren Türk Ocakları'nın şube sayısı diğerlerinden daha fazlaydi.

Halide Edip Adıvar, Ahmet Ağaoğlu, Mehmet Emin Yurdakul, Hüseyin Cahit Yalçın, Yusuf Akçura, Akil Muhtar, Fuat Köprülü ve Hamdullah Suphi Tanrı̈ver gibi dönemin edebi ve fikir insanları Türk Ocakları'nın kurulmasında yer almışlardır. (Üstel, 1997, s.42-43)

Türk Ocakları'nın kuruluşuyla ilgili olarak Anıl Çeçen ise şunları ifade etmiştir. “Osmanlı İmparatorluğu'nun giderek gerilemesi ülkedeki Türk çevreleri harekete geçirmişti. Yusuf Akçura ve Ahmet Ağaoğlu gibi Rusya kökenli Türklerin, Turancı hareketin bir araya gelmesine zemin hazırlamıştır. 1911 yılında Türk Yurdu dergisini çıkarmışlardı. 12 Mart 1912'de Türk Ocakları'nı kurmuşlardı. İlk başkan Mehmet Emin Yurdakul'du. Yitirilen savaşların yarattı̆̆ı ezikliği silmek üzere ülke çapında bir hava estirdiler. Türk kamuoyunu 1. Dünya Savaşına hazırlayan Türk Ocağı, yenilgilerin sürmesi üzerine toplumda istendiği kadar etkili olamadı. Namık Kemal'in "Osmanlı Vatanı" ve Türkçülerin "Turan Vatanı" artık düşlerde kalmıştı. Türk Ocakları genel merkezi bir Türk Enstitüsü gibi çalışarak Türk tarihinin ana hatlarını ortaya çıkarıyor ve halkın uluslaşma sürecine katkıda bulunmaya çalışıyordu. Türk Ocakları'nın amacı tüzü̈̆̈̈̈n ikinci maddesinde; İslam kavimlerinin başlıca önemlisi olan Türklerin ulusal terbiyeye bilimsel, sosyal ve ekonomik düzeylerini geliştirmek ile Türk ırk ve dininin olgunlaşmasına çalışmak biçiminde belirtiliyordu." (Çeçen, 2000, s.86-87)

İttihat ve Terakki Partisi 1913 yılından sonra tüm siyasi dernek ve oluşumları kontrol etmeyi amaçlamıştır. Hatta 1918 yılında, İttihat ve Terakki Partisi, Türk Ocaklarını yönetme talebinde bulunmuştur. Ancak Türk Ocakları mesafeli bir tavrıyla bu durumu bir sorun haline gelme- 
den çözmüş̧tür. 1912-1918 yılları arasında Osmanlı İmparatorluğu sınırları içerisinde otuz şubeye sahipti. (Karaer, 1989,s.33)

İzmir'de Maşatlık (Güneş, 2000, s.54) ve İstanbul'daki Sultanahmet Mitinglerini düzenleyen Türk Ocakları Milli Mücadelenin anlaşılmasında ve zafere giden yolda etkili olmuştur. Mitinglerin birleştirici gücünden rahatsız olan İngilizler, Türk Ocakları başta olmak üzere birçok yeri işgal etmiştir. Türk Ocaklarına ait koleksiyonları ve kitaplarına el koyulmuştur. Yöneticilerinden ve üyelerinden bazıları Malta'ya sürgüne gönderilmiştir. (Tunaya, 1988, s.438)

Kurtuluş Savaşı sırasında çalışmaları neredeyse durmuş, Türk Ocakları, Cumhuriyet' in ilanından sonra faaliyetlerine devam etmiştir. Mustafa Kemal Türk Ocakları üyesi olmuştur. Bu olaydan sonra Türk Ocaklarının hem üye sayısı hem de şube sayısı artmıştır. Mustafa Kemal'in birçok arkadaşı Türk Ocaklarına katılmıştır. Tahir Kodal, " Mustafa Kemal Atatürk ve Türk Ocakları", (TAED, 2014, s.302) hatta hazineden Türk Ocaklarına ödenek tahsis edilmiştir. 1924 yılında kamu yararına çalışan dernekler arasına girmiştir.

Mustafa Kemal'den maddi ve manevi destek alan Türk Ocakları yeni kurulan devletin ve inkılapların adeta topluma anlatıp, benimsenmesini sağlamıştır. Mustafa Kemal' in isteği doğrultusunda halkla ilgili faaliyetlerde bulunmuşlardır. Türk Ocaklarında halk sanat, kültür ve eğitim etkinliklerine katılmış çağdaş toplumların yaşayışlarıyla ilgili bilgi edinmesi sağlanmıştır. (Üstel, 1997, s.125.)

1925 yılında Atatürk Türk Ocaklarına yardım edilmesi doğrultusunda karar alınmıştır. 26 Nisan 1926 yılında Atatürk bir konuşmasında Türk Ocaklarının yeni kurulan Türkiye'nin oluşup gelişmesindeki rolüne değinmiştir. İnkılapların halk tarafından anlaşılıp benimsenmesindeki çabalarından dolayı teşekkür etmiştir. ( Kocatürk, 1999, s.389)

Mustafa Kemal birçok Türk Ocağı şubesini ziyaret etmiş ve birçoğundan övgüyle bahsetmiştir. Ancak Türkçülük idealleri hem ülkenin içinde hem de dışında bazı kesimleri rahatsız etmişti. Birçok milletten oluşan ve kontrolü altında pek çok Türk yaşayan Sovyetler Birliği Türk Ocaklar1nın faaliyetlerinden endişe etmiştir. Bu durum üzerine Sovyetler Birliği'nden bir yetkili dönemin Dışişleri Bakanı Tevfik Rüştü Aras ile görüşmüştür. (Kodal, 2014, s.304) 
Türk Ocaklarının Milli Mücadele zamanında toplumda artan etkisi CHF'nin önüne geçmesi parti genelinde rahatsızlık yaratmıştı. Aynı dönemde SCF'ye Türk Ocaklarından katılımlar CHF'deki bu konuda duyulan endişeleri artırmıştı. Türkçü kimliği sorgulanmaya başlanmıştı. Bu politika dâhilinde Türk Ocaklarının inkılapları halka anlatmamakla suçlamışlardı.

Modern Türkiye'de Türk Ocaklarının yeri neresiydi? Bu durum üzerine Türk Ocaklarının tüzügü değiştirilmiştir. Tüzükte yapılan değişiklikler şöyledir:

- "Madde 2-Türk Ocağı'nın amacı, millî bilincin kuvvetlenmesi, uygar ve sağlıkl ilerleme, millî ekonominin gelişmesidir. Madde 3-Cumhuriyet, milliyetçilik, çağdaş uygarlık ve halkçılık ülkülerini izleyen Türk Ocağı, bu ülküleri gerçekleştirmekte Cumhuriyet Halk Firkast ile devlet siyasasinda (siyasetinde) beraberdir. Türk Ocă̆ı, bu ülküleri yaymak ve aşılamak için bilim, hars ve toplum alanında mücadele eder, çaba gösterir." (Turan, 1986, s.83-84.)

Bu kurultayda Türk Ocakla mensuplarının siyasete katılmayacağı ayrıca siyasi tavrının da CHF ile beraber olacağı da eklenmiştir. Ancak Türk Ocakları Türkçülük fikrinden vazgeçmemiş ve bu yönde bir tutum izlemiştir. Hatta bu konuda CHF'den bağımsız hareket etmişlerdir. (Üstel, 1997, s.356) Tüm bunlara ilaveten, Güneydoğudaki aydınların bölgede açılacak Türk Ocaklarının kendi milliyetlerine göre kurulması istenmişti. Bu durum yeni kurulan Türkiye Cumhuriyeti'nin varlığını tehdit etmekteydi. Zira etnik milliyetçilik ülkeyi bölünmeye götürebilirdi. Bu olayda Türk Ocaklarının kapanmasına sebep olmuştur. (Özdemir ve Aktaş, 2011, s.235-262)

Atatürk, Türk tarih tezini ilk defa 1930 yılında Türk Ocakları Kurultayı'nda bahsetmiştir. Türk Ocaklarının Türk Tarihiyle ilgili üstendiği role değinmiştir. Tarihini bilen milletlerin varlıklarını ne kadar uzun süre devam ettirdiklerini dile getirmiştir. (İnan, 1947, s. 179.)

Türk Ocaklarının kapatılması ve Halkevlerinin orya çıkması Menemen Olayından sonra ortaya çıkmıştır. Atatürk, Menemen Olayından sonra çıktı̆̆ı Batı Anadolu gezisinde halkla temaslarda bulunmuş ve Türk Ocaklarının halka inkılapları anlatamadığını görmüştür. Çalışmalarının yetersiz olduğunu düşünmeye başlamıştı. (Çeçen, 2000, s.91) 
1931 yılında Halkevlerinin kurulması dile getirilmeye başlanmıştır. Türk kamuoyunda Türk Ocaklarının inkılapları halka anlatma görevinde yetersiz olduğu ve artık zamanını doldurduğu dile getirilmiştir. Bu durumla ilgili olarak Atatürk ile Çankaya'da bir toplantı bile yapılmıştır. 24 Mart 1931 tarihinde, Türk Ocaklarının CHF ile birleşmesi kararı alınmiştır. ( Akşam, 1031, s.1) 10 Nisan 1931'de Ankara'da Türk Ocaklarının son kurultayı gerçekleştirilmiştir. Kapatılan Türk Ocaklarının taşınır ve taşınmaz malları CHF'ye devredilmiştir (Üstel, 1997, s.389).

Türk Ocakları Derneği başkanı Hamdullah Suphi Türk Ocaklarının zorla kapattırıldığını dile getirmiştir. Diğer yandan CHF bu derneğin kendini feshettiğini belirtmiştir (Arıkan ve Deniz, 2004, s.415).

Türk Ocakları zorla veya kendi isteği ile kapanmış olsun, Türkiye Cumhuriyeti'nin milli birliğinin, dilinin ve tarihinin oluşmasında önemli katkılarda bulunmuştur.

\section{Halkevlerinin Kuruluşunu Etkileyen Faktörler}

Türkiye Cumhuriyeti, bilimsel anlamda geri kalmış olan Osmanlı İmparatorluğu'nun mirasını almıştı. Siyasi, ekonomik ve sosyal anlamda büyük bir yıkım geçiren Osmanlı'nın kötü etkilerini engellemek gerekiyordu. Kurtuluş Savaşı́ndan sonra asıl mücadele başlamıştı: Kalkınmak ve modernleşmek.

Atatürk rasyonel temele oturan milli tarih ve dilini bilen bir toplum yararak, milli bilinç oluşturmak istiyordu. Bu amaçla, siyaset, hukuk, sosyal ve ekonomik birçok devrim yapılmıştır.

Türkiye Cumhuriyeti'nin var olup refaha ulaşması için yapılan inkılaplar halk tarafından anlaşılamamıştı. Zaten okuma yazma bilen çok azdi. (Çeçen, 2000, s.96-97). Öyle ki, saltanat yönetimin hala devam ettiği düşünen kişiler Atatürk'e padişahım diye hitap etmiş̧tir. Yapılan ink1lapları Gâvur İcadı olarak niteleyen halka durum açıkça anlatılmalıydı.

Ülke içerisinde yaşanan bu olumsuzlukların yanı sıra 1929 Ekonomik Krizi Türkiye'yi de etkilemişti. Türk halkı bu olaydan olumsuz etkilenmişti. Yeni kurulan Türkiye Cumhuriyeti ekonomisini diş ithalatla büyümeyi hedeflemişti. Ancak uluslararası ticarette küçülme başlamıştı. Tarımsal anlamda ticareti olan Türkiye 1929 senesinde ürünlerinin çoğu 
satılmamıştı. Bu durum tarımla geçinen kesimi yani nüfusun yüzde yetmişini etkilemişti (Ezer, 2010, s.427).

Serbest Cumhuriyet Fırkasının uyguladığı politik tavır da Türkiye Cumhuriyeti'ni derinden sarsmıştı. Toplumsal anlamda yaşanan olumsuzlukları sona erdirmek amacıyla Halkevlerinin kurulmasına karar verilmiştir.

Atatürk, 1930 yılında çıktığı yurt gezisinde Türk halkının inkılapları benimsemediğini fark etmiştir. Halk ile devleti ve aydınları bütünleştirmek amacıyla, bunun yanı sıra, inkılapları halka anlatmak ve modern bir ülke olmak için birtakım çalışmalar yapılmıştır. Bu şekilde toplumsal desteğin sağlanması hedeflenmişti. Zira kitlesel destek olmadan inkılaplar yarım kalacak, dolayısıyla Türkiye Cumhuriyeti hedeflerine varamayacaktı (Sarınay, 2008, s.323).

Türk Ocaklarının kapatılma kararından sonra dünyadaki mevcut bu tip yapılar incelenmiştir. Görüldügüü üzere Türkiye'de Halkevlerine örneklik teşkil eden kurumların benzerleri diğer ülkelerde de mevcut olup söz konusu kurumlar da devletin resmi ideolojisini kitlelere benimsetme çalışmaları yapmıştır. Halkevlerinin benzer kurumlarının bulunduğu ülkeler arasında Fransa, Çekoslovakya, Meksika, Sovyet Rusya, Almanya ve İtalya gibi ülkeler bulunmaktadır.

Öncelikle Fransa'daki gelişmeleri ele alırsak Fransız İhtilali'nden çok etkilenen Atatürk, Fransız Devrimi sırasındaki Jakoben kulüpleri ve faaliyetlerini incelemiştir. Fransa'daki Jakoben Kulüpleri halkevlerine de ilham kaynağı olmuştur (Çeçen, 2000, s.82). Bu dernek yeni kurulan Türkiye Cumhuriyeti için güzel bir örnekti.

Atatürk'ün araştırttığ 1 halkevlerine model olan bir ülkede Çekoslovakya'dır. Etnik kökenleri farklı olan Çek ve Slovakların birleşerek Çekoslovakya'nın kuruluşunda etkin rol oynamışlardır. Kelime anlamı şahin olan başlangıçta jimnastik kulübü olan Sokollar zamanla siyasi bir kimlik kazanmıştır. Toplumu siyasallaşmasına katkılarda bulunan bu dernek halkın katılımı sayesinde kurulmuştur. (Demirci, 2003, s.58.).

Sokolları araştırıp Türk kamuoyuna tanıtan Vildan Aşir Savaşır 1931 yılında Avrupa'daki halk eğitimin durumunu özellikle Sokollar'dan bahsetmiştir. Bu konferansı radyoda da anlatarak halk eğitimin ve Sokolların halk eğitimindeki yerine dikkat çekilmiştir. (Toksoy, 2007,s.7). 
Sokolların halk eğitimindeki başarıları ülkede bu konuda tartışma ortamı yaratmıştı Vildan Aşir, Türkiye'de Çekoslovakya'daki eğitim ve kültür örgütleri olan Sokollar gibi bir örgütlenmeye gidilip gidilemeyeceğini, tıpkı Sokollar gibi Halkevleri ya da Halkın evlerinin kurulup kurulamayacağını araştırmıştır. (Uluskan, 2010, s.44.).

Vildan Aşir'in konferanslar ile tanıttığı Sokollar'da dikkati çeken nokta Türkiye'deki siyasal yapıya benzer bir durum ve ideolojik bir işlevle karşılaşılıyor olunmasıdır. Bir ulus devlet kurma çabasıdır. Çekoslovakya'da Çekler ile Slovakları bir araya getirerek bir ulus devlet kurma düşüncesi, Huss'ın ideallerinden birisidir. Sokolların kent veya kasaba merkezlerinde lokalleri bulunur. Sokollar'ın kent ve kasabalardaki faaliyetleri Erken Cumhuriyet döneminde Türkiye'de kurulacak halkevleriyle benzer işlevler içermektedir (Sarınay, 2008, s.360).

Ülkü dergisinde Halk Terbiyesi başlığı altında dizi halinde çıkan yazıda Meksika'daki bir örgüt anlatılmıştır. Casa del Peuble (Halkın Evi) adlı bu örgüt köylerde yer almıştır. Bu okullarda köylüye günlük yaşamindan ve üretkenliğinden koparılmadan modern yaşam ve sağlık kuralları eğitimi uygulamalı olarak verilmiştir. Bu örgüt ile halkevleri arasında ilinti kurularak örnek alınmaya çalışılmıştır. (Özdemir\&Aktaş, 2011, s.44-53).

Sovyetler Birliğine bakarsak tüm toplumsal alanları siyasal etkiye tabi tutmuştur. Politprosvet sözcüğü Rusya'da devrimci propagandanın temel kavramlarından biridir. Siyasal eğitim faaliyeti anlamına gelen bu kavram, tüm siyasi eğitim kuruluşlarının etkinliklerini kapsamıştır. Yeni Sovyet rejimi bunlara ek olarak profesyonel siyasi eğitim ve propaganda okulları açmıştır. (Şimşek, 2002, s.20).

Rusya'nın siyasi eğitim ve propaganda alanındaki bir başka profesyonel okullar zinciri ise Parti-Sovyet okulları olmuştur. Bu okulların amacı Parti'nin ideolojisini halka yayacak ajitatörler ve propagandacılar yetiştirmektir. CHP'nin 1931'de kurmuş olduğu Halk Hatipler Teşkilatı'nın amacı da Parti'nin ideallerini halka anlatacak hatipler yetiştirmektir. İki ülke arasındaki rejim farkına karşın, amaçları aynıdır. (Şimşek, 2002, s.23).

1930'lara gelindiğinde Alman şehirlerinde pek çok Yurttaş Evi kurulmuştur. Çok amaçlı toplumsal merkezler olarak düzenlenen bu evler kurslar, konferanslar, törenler, spor etkinlikleri yoluyla insanları eğitme- 
yi ve kaynaştırmayı amaçlamıştır. Almanya'da yeni rejim ekonomi, siyaset ve kültür başta olmak üzere tüm toplumsal alanları yönlendirmiş, Yurttaş Evleri ve Toplum Evleri ile insanlara yeni bir bakış açısı kazandırılmaya çalışılmıştır. (Çeçen, 2000, s.91).

İtalya'da Dopollavoro adlı yurttaş evleri bulunmaktaydı. Eğitimin çocukken başladığına inanılmaktaydı. 5 yaşından itibaren kız ve erkek çocukları ailelerinin yanından alınarak eğitilmiştir. Düşünsel, bedensel olarak eğitim alan bu çocuklar spor aktiviteleri de yaptırılmıştır. Bu şekilde yeni neslin bedensel ve ruhsal olarak sağlıklı olması hedeflenmiştir. (Yeşilkaya, 2003, s.69).

\section{Halkevlerinin Açılması}

1931 yılında Türk Ocaklarının kapanmasından sonra, Cumhuriyet rejiminin halk tarafından benimsenmesi amacıyla CHF'nin bir kuruluşu olan Halkevleri açılmıştır. Rasyonel akıl, bilimsel bilginin kaynaşmasıyla modern Türkiye'nin oluşması görevini üstlenmesi planlanmıştı. Bağnaz, çağdışı kalıpları yıkan akılcı rejimi destekleyen aynı zamanda milli dil ve tarih bilinciyle kaynaşmış ve iyi eğitim almış bir toplum yaratarak Yeni kurulan Cumhuriyet'in varlığını sürdürmesi sağlanacaktı.

Gençleri zararlı alışkanlıklardan uzak tutan, okuyan düşünen analiz eden nesiller yaratarak, halkın modernleşmesi bunun yanı sıra hem kırsalda hem de kentlerde yaşayan herkesi eğiterek, cehaleti, bağnazlığ1 yok etmeyi hedeflemişti. Vicdanı hür, din ve siyaseti aynı potada eritmeyen milliyetçi ve halkçı toplum oluşturmak gibi nedenlerle açılmıştır. (Zürcher, 2006, s. 282). Ancak halkevlerinin açılış nedenleri çok çeşitlidir.

1925 yılındaki Şeyh Sait İsyanının rejimi tehdit etmesi ve ülkede huzursuzluk çıkarması, 1930 yılında Menemen' de Derviş Mehmet ve birkaç kişinin yedek subay öğretmen Kubilay'ı şehit etmeleri, 1928 yılında kurulan Serbest Cumhuriyet Firkası'nın gericilik faaliyetleri sonucunda, Atatürk halkın eğitilmesi için halkevlerinin kurulmasını onaylamıştır (Çeçen, 2000, s.108-109).

Halkevleri Atatürk İnkılaplarını esas almıştı. Cumhuriyetçi, milliyetçi ve halkçı modern ve bilimsel anlamda ileri bir devlet olabilirdi. Laik ve demokrasiye inanan toplum hedefini halkevleriyle gerçekleştirebilirdi. Milliyet, cins ve sosyal konumla ilgili ayrıcalıklar ortadan kalkması top- 
lumsal kaynaşmanın ve bilincin doğmasını kolaylaştırırdı. (Toksoy, 2007, s.31). Ayrıca halkevleri sadece gençleri değil yetişkinlere de hitap etmesi önemli bir noktayı teşkil ediyordu.

Halkevlerine olan ihtiyaç bir anda ortaya çıkmamıştır. 1925 yılında Türk Ocakları varlığını sürdürdüğü sırada ilk defa dile getirilmiştir. Türk Ocaklarının, Halkevine dönüşmesi nezdinde görüşler ileri sürülmüştür. 10 Ekim 1925 yılında İstanbul'da yapılan Türk Ocakları kongresinde Ocakların toplumsal görevleri olduğu ve bu sebeple bir dernek değil Halkevi olması önerisi yapılmıştır (Üstel, 1997, s.160).

Halkevlerinin kuruluşu Türk Ocakları kapanmadan üç ay önce kamuoyunda yer almaya başlamıştır. 1500 kişi kapasiteli, içerisinde kütüphane, sinema vb. bulunan, konferanslar verilecek halkevlerinin kurulacağ1 gazetelerde yer verilmişti (Özdemir ve Aktaş, 2011, s.244). Bu olay Türk Ocaklarına henüz kapanmadan alternatif arandığını gözler önüne sermektedir.

18 Mayıs 1931'detertip edilen CHP'nin kongresinde Halkevlerinin kurulmasına karar verilmiştir. Bu karardan sonra Halkevlerinin kurulması için devletin tüm kaynaklarından yararlanılacaktı. Recep Peker 16 Ekim 1931'de Darülfünun 'da verilen CHF programı ve Halkevleri ile ilgili kararı duyurmuştur (Akşam, 1931, s.1-2).

CHF programında milliyet, cinsiyet ve din ayrımı gözetmeksizin müşterek değerlere bağlı bir millet oluşturmak gerektiği belirtilmiştir (Şimşek,2002,s.60). Bu ideali gerçekleştirmenin yolunun halkevlerinden geçtiği belirtilmiştir.

Halkevleri 19 Şubat 1932 tarihinde açılmış ve aynı gün tam 14 merkezde hizmete giren şubeleri ile Türk kültür tarihindeki yerini almıştır. Bunlar Adana, Afyon, Ankara, Aydın, Bursa, Çanakkale, Denizli, Diyarbakır, Eskişehir, İstanbul, İzmir, Konya, Samsun ve Van Halkevleridir. Türk Ocaklarının kapatılmasından yaklaşık bir yıl sonra açlan Halkevlerinin genel merkezi Ankara'daki Türk Ocağı binası olmuş, açılış töreni de burada yapılmıştır. Yani bir anlamda Halkevleri, Türk Ocakları mirasinı devralmıştır.

Halkevlerini kurma görevi Maarif nazırı olan Reşit Galip'e verilmişti. Bu konuda çalışmalar yapmaya başlayan R. Galip Ankara Türk Ocağ Binası'nda bir toplantı tertip etmiş, dönemin önde gelen isimlerini bu toplantrya davet etmiştir. Şevket Süreyya Aydemir, Recep Peker, Hasan 
Cemil Çambel, İsmail Hüsrev Tökin ve Vidan Aşir Savaşır toplantıya katılan kişilerden bazılarıdır (Arıkan\&Deniz, 2004, s.407). Alınan diğer bir karar göre; Türk Ocaklarındaki mallar Halkevlerine devredilmiştir.

Reşit Galip başkanlığında hazırlanan Halkevleri tüzüğü şöyledir: “Halkevleri sadece CHF'lilere değil, tüm halka açıtıtr. Yönetimi CHF'lilere aittir. Idare heyetinde memurlar yer alabilir. Halkevlerini açma kararı CHF İdaresi'ne ancak kurumun düzenlemesi ve şekli il idare heyetleri tarafindan yürütülecekti. Halkevi açmak için belli şartlar vardır: şube faaliyetlerine uygun şartlar să̆lanmalıdır. Bina ve maddi kaynakları temin etmesi gerekmektedir. Halkevlerine yapılan bağışlar Halkevi idare heyetince kabul edilecekti. Halkevlerine ait salonlarda diğer partilerle ilgisi olmayan bunun yan sira CHF'nin ilkeleriyle ters düşmeyen bütün toplantılar yapılabilirdi. Ancak içki içmek ve kumar oynamak yasakt. Halkevlerinde ayrica protokol yoktu. "(Özdemir\&Aktaş, 2011, s.246).

Halkevleri denetlenmekteydi. Bu amaçla CHF Genel Sekreterliğine üç ayda bir rapor gönderilmiştir. Halkın eğilimlerine göre faaliyet alanı bulması için halkevinin dokuz şubesi oluşturulmuştur. Muhakkak, her şubede her şey kayıt edilirdi. Modernleşme amacıyla belirli aralıklarla balolar düzenlenebilirdi. CHF ve Halkevi mensupları düğün ve nişanlarını Halkevlerinde yapabilirdi. (Sarınay, 2008, s.367).

Tarık Zafer Tunaya da konuyla ilgili olarak “CHF'nin Türk Ocaklarmın yerine geçmek ve kültür politikasını tahakkuk ettirmek üzere kurduğu bu müesseseler, aynı zamanda Türk Ocaklarının manevi varisi de sayılmışlardır." sözleriyle Halkevlerinin tanımını yapmıştır (Tunaya, 2008, s.13).

19 Şubat 1932 tarihinde Halkevleri açılmıştır. Aynı tarihli Akşam Gazetesi'nde bu olay şöyle anlatılmıştır: "Memleketin muhtelif yerlerindeki 43 halkevi merasimle açılacaktır. Şu ana kadar 15 bin kişi halkevlerine kaydolmuştur." (Akşam, 1932, s.1).

19 Şubat 1932'e kadar hazırlıkları biten Aydın, Bolu, Diyarbakır, Eminönü, Eskişehir, Afyon, Ankara, İzmir, Bursa, Çanakkale, Denizli, Konya, Samsun ve Malatya'da yaklaşık on dört tane halkevi açılmıştı. Edirne, Gaziantep, Giresun, Silifke, Trabzon, Van, Yozgat, Kastamonu, Kayseri, Antalya, Bilecik, Kırklareli, Kocaeli, Kütahya, Ordu, Rize, Sinop, Tekirdağ ve Zonguldak'taki Halkevleri hazırlıklarını tamamlayamadıkları için 24 Haziran 1932 tarihinde açılmışlardı (Özdemir\&Aktaş, 2011, s.247). 
Halkevlerinin açılışı çok kalabalık olmuş, merkez binanın önünde kuyruklar oluşmuştur ve açılış Radyo' dan da halka aktarılmıştır.

Ankara Halkevindeki açılış törenine katılan Recep Peker konuşmasında, halkevlerinin neden kurulduğunu açıklamıştır. Recep Peker, düzenli eğitim öğretim veren halkevlerinin halkı eğitmek amacıyla kurulduğunu belirtmiştir. Milli bilinçle kaynaşan toplum kendisine ilim ve fenni rehber alarak modernleşeceğini dile getirmiştir. Bu hedef için yetişkinler eğitilmelidir (Zeyrek, 2006, s.24).

\section{Halk Evlerinin İdaresi}

Halkevleri CHF'nin eğitimle ilgili kuruluşudur. Zaten idaresi incelendiği zaman CHF bağlantıları dikkat çekmektedir. Bu yakınlık daha sonra halkevlerinin kapanma sürecinde en çok eleştiri aldığı noktadır diyebiliriz.

Halkevleri başkanları zamanla Fırkanın bölgedeki teşkilatı tarafından seçilmeye başlanmıştır. Bu konuda tek istisna Ankara Halkevi idi ve bu doğrultuda Halkevlerinin merkezi Ankara kalmıştır. 1932 tarihli Halkevleri Talimatnamesi 'ne göre Halkevi İdare Heyeti, şube komiteleri tarafından belirlenen birer temsilciden oluşmaktadır. (Özdemir\&Aktaş, 2011, s.252). İki yılda bir yapılan seçimlerde üyeler yeniden seçilebilme hakk1na sahiplerdi. Halkevleri çalışma raporlarını üçer aylık periyotlarla Fırka Genel Sekreterliği'ne göndermek zorundaydılar. Milletvekilleri de Halkevlerini denetlemekle görevlendirilirlerdi. Halkevlerinde kararlar oy çoğunluğu ile alınır, şayet oylar eşit olur ise başkanın oy kullandığı tarafın kararı geçerli olurdu (Zeyrek, 2006, s.30).

\section{Halk Evi Binaları}

Halkevine ait binalarda, Altı Oklu bayraklar, Atatürk heykelleri, özdeyişler ve Türk Bayrağı CHF politikalarına dair unsurlar göze çarpmaktadır. Binalar Cumhuriyet Meydanlarında yer almaktadır. Ancak mersin Halkevi'nde durum değişiktir. Bu halkevi inşa edildikten sonra Cumhuriyet Meydanı oluşturulmuştur. Halkevleri binalarının yeri coğrafi konumuna göre farklılıklar göstermekteydi. Mesela, kıyı kentlerinde sahil kenarında inşa edilmişlerdir. Dini yapılara yakın konumlandırılmıştır. 
Binalarda bulunan balkon hitabet amaçlı kullanılmıştır. (Aktaş ve Deniz, 2011, s.255).

Halkevlerinde teras bulunmaktaydı ve yaz aylarında sinema balo gibi sosyal faaliyetler için kullanılmıştır (Sarınay, 2008, s.345). Salon, idari kısım, kütüphane ve açık alan olarak da meydan, bahçe ya da avludan oluşan bölümleri vard1.

Halkevlerinde tiyatro temsili yapılarak sanatla halk kaynaştırılmaya çalışılmıştır. Binalarda yer alan gardırop odası kısmı ise modern hayatın bir alışkanlığını halka kazandırmayı amaçlıyordu (Durukan ve Ulusu, 2009, s. 38).

Halkevinin kira, elektrik, yakıt gibi belli başlı giderleri için maddi kaynak gerekmekteydi. Masraflar yardımlar, devlet bütçesinden ve Halkevinin bulunduğu CHF parti il örgütü tarafından karşılanmaktaydı. Yıllık bütçe yapıp bulundukları yerdeki parti örgütüne onaylatırlardı. Zamanla devletin halkevlerine verdiği ödenek azalmıştır. Zira halkevi sayısı fazlalaşmıştır. Bu yüzden yardımların miktarı azalmıştır.

Atatürk ölünce vasiyeti uyarınca menkul mallarından bir kısmı da Halkevlerine verilmiş ve vergiden muaf tutulmuştur. CHF Genel Sekreterliği ise Halkevlerini gönderilen parayı gerekli yerlerde kullanmaları, tasarruflu olmaları gibi konularda uyarmıştır. Fakat gelirlerin büyük bölümünün devlet tarafından sağlanması özellikle çok partili dönemde eleştiri konusu olmuştur. Muhalefet olan Demokrat Parti, devletin olduğu iddia edilen ve devlet tarafından para tahsis edilen bu kurumdan kendilerinin yeterince faydalanamadıklarını ileri sürecektir.

19 Şubat 1935 tarihinde, yani halkevlerinin üçüncü kuruluş yıldönümünde İsmet İnönü, Halkevlerinin açılma sebeplerini açıklamıştır: "Halkevlerinin üçüncü yıldönümünü kutluyoruz. Bu anda ülkenin seksen kadar Halkevinde imkânı olanlar bugünkü toplantımızı dinliyorlar. Halkevleri üç yıldan beri kendi varlıkların kültürel alanda duyurmuşlardır. Halkevlerinin şu vazifesine bütün Halkevlerinin üçüncü yıldönümünü kutluyoruz. Bu anda ülkenin seksen kadar Halkevinde imkânı olanlar bugünkü toplantımızı dinliyorlar. Halkevleri üç yıldan beri kendi varlıklarım kültürel alanda duyurmuşlardır. Halkevlerinin şu vazifesine bütün Halkevi üyelerini dikkatini çekmek isterim. Halkevleri sosyal büyük bir ödevi üzerlerine almışlardır. " (Oral, 2002, s.50$81)$. 
Cumhuriyet Halk Fırkası tarafından halkevlerinin 1935 yılı sonuna kadar olan çalışmaları hakkında bir broşür yayınlanmıştır. 136 sayfadan oluşan broşür Nafi Atuf Kansu'nun düşüncesiyle İçişleri Bakanlığı vekili ve Cumhuriyet Halk Fırkası Genel Sekreteri Şükrü Kayanın muvafakatı alınarak, Behçet Kemal Çağlar tarafından yazılan ve başta İsmet İnönü'nün 5.7.1934 yılındaki Kamutaydaki 61 nutuklarından alınan ve Şükrü Kayanın Halkevleri hakkındaki yazısında ise halkevlerinin amaçlarından şöyle bahsedilmiştir.

"Atatürk Inkılâbının Türk ve Türkçü olması ana vasıflarındandır. İnkılâbımiz Türk milletinin cihan tarihi ile başlayan medeni ve sosyal yaşama ve yaşayış safhalarından alınmış ve onun istidat ve ihtiyacına uygun olarak tespit edilmiş reel kaidelerdir. Türk olan İnkılâbımız zaruri ve tabii olarak Türkçüdür de. Türk ve Türkçü vasıflarını esash bir şiar olarak bünyesinde taşıyan ve yaşatan bu İnklâbın milli olması etmez. Bu gayeye ermek için halka dayanmayı da en sağlam ve kısa yol olarak bilir." (Kara, 1999, s,69).

Her münevver Türk için mevki ve hayatını temin eden ve millete borçlu olduğu bilgisini asil ve dürüst tesviye çaresi hatta vatanseverlik ve insanlığında icabı, bildiğini hiçbir suretle bilmemekten mesul olmayan yurttaşlarına öğretmektir.

\section{Halkevlerinin Kapatılması}

Halkevlerinin çalışması, işleyişi tek parti iktidarında herhangi bir sorun ortaya çıkarmamıştır aksine iktidarın bir yan kuruluşu olarak, cumhuriyetin ilke ve değerlerine bağlı olarak yurt genelinde faaliyet göstermiştir. Ancak Çok partili sisteme geçilmesi ile birlikte halkevlerinin statüleri, siyasetle olan ilişkileri ve devlet tarafından bu kuruluşlara yapılan ödenekler tartışılmaya başlanmıştır. Özellikle de Demokrat Parti'nin 1946 seçimleri sonrasında meclise 60 milletvekili ile girmesi sonrasında, bütçe toplantılarında halkevlerinin durumu sorun oluşturmaya başlamıştır. Buna gerekçe olarak ise halkevlerinin yalnızca bir eğitim kurumu olmadığı, Cumhuriyet Halk Partisi'nin siyaseti ile yakın ilişkisinin bulunduğu ileri sürmüştür (Kaş, 2007, s. 34).

1946 yılında çok partili siyasi hayata geçilmesi ile birlikte Halkevlerinin CHP'ye bağlılığının hukuksal bir zemini de kalmamıştır. Sistemin değişmesi ile birlikte halkevleri yeni şartlara uyum sağlamak zorunda 
kalmıştır. Halkevlerinin yeniden düzenlenmesi amacıyla bütün siyasi parti teşkilatlarından Halkevleri ile ilgili görüşler istenmiştir ancak muhalefet partilerinden bu konuda destek alınamamıştır. Yine aynı amaçla Cumhuriyet Halk Partisi'nin 1947 yılındaki 7. büyük kurultayında Halkevlerinin durumu tartışılmıştır (Turan, Cilt 1, TÜBA,s.12).

Halkevlerinin mecliste muhalefet tarafından tekrar gündeme getirilmesi Adnan Menderes tarafından 1947 yılında gerçekleşmiştir. Adnan Menderes Halkevlerine yapılan maddi destekleri Cumhuriyet Halk Partisi hesabına yatırılmış olduğu ve akıbetinin de belli olmadığını iddia etmiştir. Bu konuşmada Halkevleri üstü kapalı şekilde haksız maddeyi gelir sağlamakla suçlanmıştır (Akşin, 2010, s.205).

$\mathrm{Bu}$ sorun ile ilgili yine muhalefetten gelen bir açıklama ise halkevlerinin siyasi Parti'den doğmuş olması ve Cumhuriyet Halk Partisi'ne hizmet ettiğinden dolayı siyaset ve ilişkisini kesene kadar maddi destekten yoksun bırakılması gerektiği şeklinde bir önerge verilmiştir. Sonuç itibarıyla verilen bu önerge kabul edilmemiş ve halkevlerinin ömrü biraz daha uzatılmıştır (TBMM Tutanak Dergisi, 1947, s. 558).

Ancak bu uzun süren tartışmalar sonucu halkevleri 14 Mayıs 1950'de Demokrat Parti'nin iktidara gelmesi ile faaliyetleri yavaşlatılır. 8 Ağustos 1951'de mecliste çıkarılan 5830 Sayılı yasa ile halkevleri resmen kapatılır. Halkevleri fiilen y1llar önce faaliyetlerini kaybetmişlerdi. 11 Ağustos 1951'de bu yasa Resmi Gazete' de yayınlanarak yürürlüğe girmiştir (Özacun, 2001, s.10).

\section{Sonuç}

Halkevlerinin kuruluş amacındaki etkin kuralın Cumhuriyet'in getirmiş olduğu laik, bilimsel ve düşünen yurttaşlık anlayışıyla, Cumhuriyet'in ilke ve inkılaplarının halk tarafından daha kolay anlaşılmasını, yeniliklerin halkın yaşantısına yansıtılmasını ve inkılapların halk tarafından benimsenmesini sağlamaktır.

Halkevleri, kent kent organize olarak Türk İnkılâplarının hayata geçirilmesini hedeflemiştir. Bu doğrultuda çağdaş bir ülkeyi hedefleyen Atatürk laikliğe dayalı bir yönetimi benimsemişti. Dini siyasetle alet etmeden özgür düşünceli bireylerin ülkenin kilometre taşı olduğunun bilincindeydi. 
Yeni kurulan Cumhuriyet'te eskiye ait ideoloji veya tutumun yer almaması için çaba gösterilmiştir. Bu doğrultuda, halkevleri eskiye ait ideoloji ve tutumu geride bırakmış ve toplumsal olarak bu hususun benimsenmesi için çalışmıştır.

1932-1950 yılları arasında önemli kültürel, sosyal, eğitsel, sportif türü faaliyetlerde bulunmuş, yukarıda belirtilen zaman dilimi faaliyet dönemi içerisinde bölgenin önemli bir kültür merkezi haline gelmiştir. Özellikle 1932-1938 yılları arasında Yüce Önder Mustafa Kemal Atatürk'ün de yoğun ilgisi ile Cumhuriyet'in temel ilkelerinin halka anlatılması ve halkın belirli konularda aydınlanması ve sosyalleşmesi açısından önemli katkılar sağlamıştır. Gerek düzenlenen okuma-yazma kursları, dil kursları, el işi kursları ve gerekse de milli bayramlarda yapılan faaliyetler ile halkın milli değerlere sahip çıma ve milli bayramlara içtenlikle katılmaları sağlanmaya çalışılmıştır.

Halkevlerinin toplum üzerindeki etkileri özellikle eğitim ve kültürel faaliyetleri üzerinde büyük bir yer edinmiştir diyebiliriz. Halkevleri Atatürk İnkılaplarını esas almıştır. Cumhuriyetçi, milliyetçi, halkçı modern ve bilimsel anlamda ileri bir devlet olabilir. Laik ve demokrasiye inanan toplum hedefini halkevleriyle gerçekleştirebilir düşüncesi vardı. Ayrıca halkevleri sadece gençleri değil yetişkinlere de hitap etmesi önemli bir noktayı teşkil ediyordu.

Gençleri zararlı alışkanlıklardan uzak tutan, okuyan düşünen analiz eden nesiller yaratarak, halkın modernleşmesi bunun yanı sıra, hem kırsalda hem de kentlerde yaşayan herkesi eğiterek, cehaleti, bağnazlığ yok etmeyi hedeflemişti. Vicdanı hür, din ve siyaseti aynı potada eritmeyen milliyetçi ve halkçı toplum oluşturmak gibi nedenlerle açılmış bu yönde faaliyetlerini devam ettirmiştir.

Halkevlerinin Dil, edebiyat ve tarih şubesi halkın genel kültürlerin artırılması, Cumhuriyet Halk Partisi ve yeni kurulmuş Türkiye Cumhuriyeti'nin ilkelerine uygun olarak vatan sevgisi ve yurttaşlık anlayışının, toplumda yükseltilerek konferansların hazırlanmasına öncülük etmiştir. Bunun yanında halk dilinde yaygın olarak kullanılan fakat yazıya ve edebiyata dökülmemiş olan kelimelerin atasözlerinin ve masalların araştırılması, Türkçe kelimeleri ve deyimleri toparlamak, farklı alanlarda çalışmaları olan ünlü Türk büyüklerinin anılması, dergilerin hazırlanma- 
S1 ve bu yayınların dağıtılarak toplumun bilinçlendirilmesinin sağlanmasi gibi görevlerde bulunmuştur.

Halkevi'nin açılışından itibaren faaliyet göstermekte olan diğer bir önemli şubesi ben halk dershaneleri ve kurslar şubesidir. Bu şubenin amacı halkın Türkçe yönelik okuma ve yazma becerilerinin geliştirilmesine sağlamaktır.

Spor şubesinin amacı ise gençlerin spora yönelik ilgi ve isteklerinin artırılması, gerçekleştirilen spor faaliyetlerinin planlı ve bilimsel temellere dayandırılması, halkın sağlıklı ve dürüst bireyler olarak yetiştirilmesinin sağlanması, ulusal spor faaliyetleri ve bayramlar düzenleyerek toplumun bilgisinin spora çekilmesini öngörmektir. Sosyal yardım şubesi, savaştan çıkmış zor şartlar içerisinde yaşamını sürdürmeye çalışalım toplumun içerisindeki ihtiyaç sahibi kişilerin, öğrencilerin, kimsesizlerin ve yardıma muhtaç olan kişilerin ihtiyaçlarının karşılanması, gerekli durumlarda iş temin edilmesi gibi amaçlar için kurulmuştur. Köycülük şubesinin köylerin gelişmesinin sağlanması, iktisadi ve estetik açıdan köylerin geliştirilmesi, köy ile kentte yaşayanlar arasındaki ilişkilerin güçlendirilmesi gibi önemli amaçları bulunmaktadır.

Çok partili sisteme geçişte halkevleri parasızlık gibi bir sorunla karşılaşmıştır. Parasızlık hem de aydınların halkevlerinden uzaklaşmalarıyla iyice zor durumda kalan halkevleri düzenli olarak çıkarmaya çalıştıkları dergileri de bazen çıaramaz hale gelmişlerdir. Demokrat Parti'nin 1946'da meclise girmesi halkevlerinin kapatılması ile ilgili tartışmaları başlatmıştır. Tartı̧̧malar sonucu halkevleri 14 Mayıs 1950'de Demokrat Parti'nin iktidara gelmesi ile faaliyetleri yavaşlatılır. 8 Ağustos 1951'de mecliste çıkarılan 5830 Sayılı yasa ile halkevleri resmen kapatılmıştır. 


\title{
EXTENDED ABSTRACT
}

\section{Turkish the Modernization Community Centers of Place}

\author{
Songül Gökçe \\ Bülent Ecevit University
}

Together with the Republic, it was envisaged to establish community houses to educate the society of the new state, to emphasize that the state attaches importance to the people, to ensure the adoption of the reforms and to involve the people in production and innovation.

People's Houses were established to create a person who gathered around the Republic's secular, scientific thinking and citizenship culture and to strengthen the administration. Through these houses, the public will be engaged in education, art, health, village affairs and become competent in these fields.

People's houses were thought and acted as institutions that read, listen, criticize, attach importance to science, engage in sports, cultivate themselves in fields such as art, history and literature, and try to create productive new people interested in cultural activities. The low level of education of the public and the desire to quickly implement the innovations were in conflict. The fact that this difficulty was revealed also showed the need of the public for education.

In addition, the values of the Republic should be adopted and explained to the public in literacy trainings and cultural activities. Unless this situation is solved effectively and importantly, the revolutions will not be able to find any response in public again and it will lose its validity. The preservation of the principles and values could only be possible with public support. While emphasizing the impact of the community houses on society in this way, we will examine how they continue their activities, and thus inform the public about the developments in the process of educating, enlightening, and joining the public. Halkevleri was opened on 19 February 1932 and took its place in the history of Turkish culture with its branches opened in 14 centers on the same day. The headquarters of the public houses opened about a year after the closure of the Turkish Hearths became the Turkish Hearth building in Ankara and the opening ceremony was held here. In other words, com- 
munity houses took over the heritage of Turkish Hearths. A quarterly report was sent to the Secretariat General of CHF for the supervision of public houses. Nine branches of the community center were established in order to find activity according to the tendencies of the people.

In public houses, decisions are taken by majority vote, and if the votes are equal, the decision of the party to which the chairman votes is valid. From the foundation until the death of Atatürk, the activities of the community houses were quite high. By the year 1938 Turkey has participated in the activities of community centers close to half of the population. The reason for this situation is that the new administration of the Republican People's Party gives priority to the establishment of village communities in villages in order to ensure connection with the Village Institutes for the development of the villagers and the community houses in the cities. Since the number of participation in community houses has decreased gradually, since 1947 new community houses have not been opened. Radio, cinema, newspapers and politics of the period had negative effects on the decrease of the importance and function of public houses. II. After the end of World War II, a large increase in the number of radio and cinema were seen in Turkey. The newspapers kept their prices constant and added supplements to attract readers.

The Republican People's Party continued to serve as a cultural branch as it used to be In 1950, the ruling Democratic Party has changed the result of his politics and community centers with Law No. 5830 in 1951 to close all community centers in Turkey, real property was transferred to the treasury. The Constitutional Court, which was established after the 1960 revolution, abolished the law no On the application of the Republican People's Party and the transfer of the immovables of the Republican People's Party to the treasury. However, the Republican People's Party did not make any effort to revive the community houses by restoring the buildings belonging to the community houses.

Party leader İsmet İnönü, He said that public houses will continue their activities by merging with Turkish Cultural Associations established in 1960. Since 1946, the Republican People's Party, which has moved away from the public Even in the mid-1960s, it seems that he maintained the same attitude. In the 1930s and 40s, community houses made great strides today, government agencies, foundations, associations and private organizations that are not related to each other It has undertaken. This is proof that the purpose of 
establishment of the community houses did not lose importance even in the 2000s.

\section{Kaynakça / References}

Memleketin muhtelif yerlerindeki 43 halkevi merasimle açılacaktır. (25 Mart 1031). Akşam Gazetesi. s.1.

Akşin, S. (2010). Kısa Türkiye tarihi. 11. Bsm, İstanbul:Türkiye İş Bankası Kültür Yayınları, 205.

Akçura, Y. (2012). Türkçülük: Türkçülü̈̆̈̈̈n tarihsel gelişimi, İstanbul:İKS Yayinlar1, 25-26.

Çeçen, A. (2000). Atatürk'ün kültür kurumu halkevleri. Cumhuriyet Kitapları, İstanbul, 86-87.

Demirci, A. (2003). Tek parti döneminde siyaset- gençlik teşkilatı ilişkilerine bir örnek: Gençlik teşkilatı tasarıları. Ankara Üniversitesi Siyasal Bilgiler Fakültesi Dergisi, 58(2), 58.

Durukan A. ve Ulusu, U. (2009). Türkan, Cumhuriyetin kültür kurumu olarak halkevi binaları. İTÜ dergisi/a, mimarlık, planlama, tasarım. 7(1), 38-49.

Ezer, F. (2010). 1929 krizinin Türkiye'ye etkileri. Fırat Üniversitesi Sosyal Bilimler Dergisi, 20(1), 427-442.

Güneş, G. (2000). Mütareke döneminde İzmir'deki Türk Ocağı ve faaliyetleri. DEÜ Atatürk Ilkeleri ve Inkılap Tarihi Enstitüsü Çă̆daş Türkiye Tarihi Araştırmaları Dergisi, 3(9-10), 54-57.

İnan, A. (1947). Türk Tarih Kurumunun kuruluşuna dair. Belleten, 11(42), 179.

Kara, A. (1999).Türkiye' de halkevleri. Ankara:Halkevleri Yayınları, 22.

Kaya, B. (2008). Bir halk eğitimi kurumu olarak Izmit halkevi (1932-1951). Yüksek Lisans Tezi, Sakarya Üniversitesi, Sosyal Bilimler Enstitüsü, 12.

Kaş, H.(2007). Isparta halkevi çalışmaları ve Ün Dergisi ( 1934- 1950). Yüksek Lisans Tezi, Hacettepe Üniversitesi, Atatürk İlkeleri ve İnkılâp Tarihi Enstitüsü, 34 .

Karaer, İ.(1989). Türk ocakları ve inkılâplar. Basılmamış Doktora Tezi, Ankara Üniversitesi Türk İnkılâp Tarihi Enstitüsü, Ankara, 33.

Kodal, T. (2014). Mustafa Kemal Atatürk ve Türk Ocakları. A. Ü. Türkiyat Araştırmaları Enstitüsü Dergisi TAED, 52, 302. 
Kocatürk, U. (1999). Doğumundan ölümüne kadar kaynakçalı Atatürk Günlüğü. Ankara:Atatürk Araştırma Merkezi Yayını, 389.

Ortaylı, İ. (2018). Osmanlı düşünce dünyası ve tarih yazımı. İstanbul:İş Bankası Kültür Yayınları, 103-130.

Oral, M. (2002). Halkevlerinin toplumsal ve kültürel işlevleri. Atatürk Araştırma Merkezi Dergisi, 53(18), 499-520.

Özacun, O. (2001). CHP halkevleri yayınları bibliyografyası, İstanbul:Kitap Matbaacilik, 10.

Özdemir, Y. ve Aktaş, E. (2011). Halkevleri (1932'den 1951'e). A.Ü.Türkiyat Araştırmaları Enstitüsü Dergisi, 45, 235-262.

Sarınay, Y.(2008). Türk milliyetçiliğinin tarihi gelişimi ve Türk Ocakları. İstanbul:Ötüken Yayınları, 323.

Şimşek, S. (2002) Bir ideolojik seferberlik deneyimi halkevleri 1932-1951. İstanbul:Boğaziçi Üniversitesi Yayınevi, 20-23.

TBMM. (1947). Yirmi beşinci Birleşim. 558.

Toksoy, N. (2007). Bir kültürel kalkınma modeli olarak halkevleri. Ankara:Orion Yayınevi, 29-30.

Turan, Ş. (1986). Türk devrim tarihi. Ankara:Bilgi Yayınevi, 21.

Turan, Ş. (2000).Etkin bir eğitim, kültür ve sosyal dayanışma kurumu olarak halkevleri. Bilanço 1923-1998, 1, 205-210.

Tunaya, T. Z. (1988). II. Meşrutiyet Dönemi. !1. Cilt) Türkiye'de siyasal partiler içinde (s.438), İstanbul:Hürriyet Vakfı Yayınları.

Tunaya, T. Z. (2008). Türkiye'de siyasi partiler. I. İstanbul:İletişim Yayınları, 10.

Üstel, F. (1997). Türk ocakları. İstanbul:İletişim Yayınları, , 42-43.

Yeşilkaya, N. G. (2003). Halkevleri: İdeoloji ve mimarlık, iletişim yayınları. İstanbul, 29-30.

Zürcher, E. J. (2006) Modernleşen Türkiye'nin tarihi. İstanbul:İletişim Yayınları, 65-68.

\section{Kaynakça Bilgisi / Citation Information}

Gökçe, S. (2019). Türk Modernleşmesinde Halkevlerinin Yeri. OPUSUluslararası Toplum Araştırmaları Dergisi, 14(20), 2327-2350. DOI: 10.26466/opus.656129 